\section{To: (Receiving Organization) DISTRIBUTION}

\section{Proj./Prog./Dept./Div.:}

VAPOR/AS/SPECIAL/ANALYTICAL/ SUPPORT

\section{Originator Remarks:}

SST-241-C-204. SAMPLING USING THE VAPOR SAMPLING SYSTEM

3. From: (originating Organization) SPECIAL ANALYTICAL SUPPORT $8 \mathrm{C} 530$

6. Design Authority/ Design Agent/Cog Engr.:

RICKY MAHON 3-7437

11. Receiver Remarks:

11A. Design Baseline Document?

[] Yes

[X] No
4. Related EDT No.:

$N / A$

7. Purchase Order No.:

$$
N / A
$$

9. Equip./Component No.:

N/A

10. System/Bldg./Facility:

$622 \mathrm{G}$

12. Major Assm. Dwg. No.:

N/A

13. Permit/Permit Application No.: N/A

14. Required Response Date:

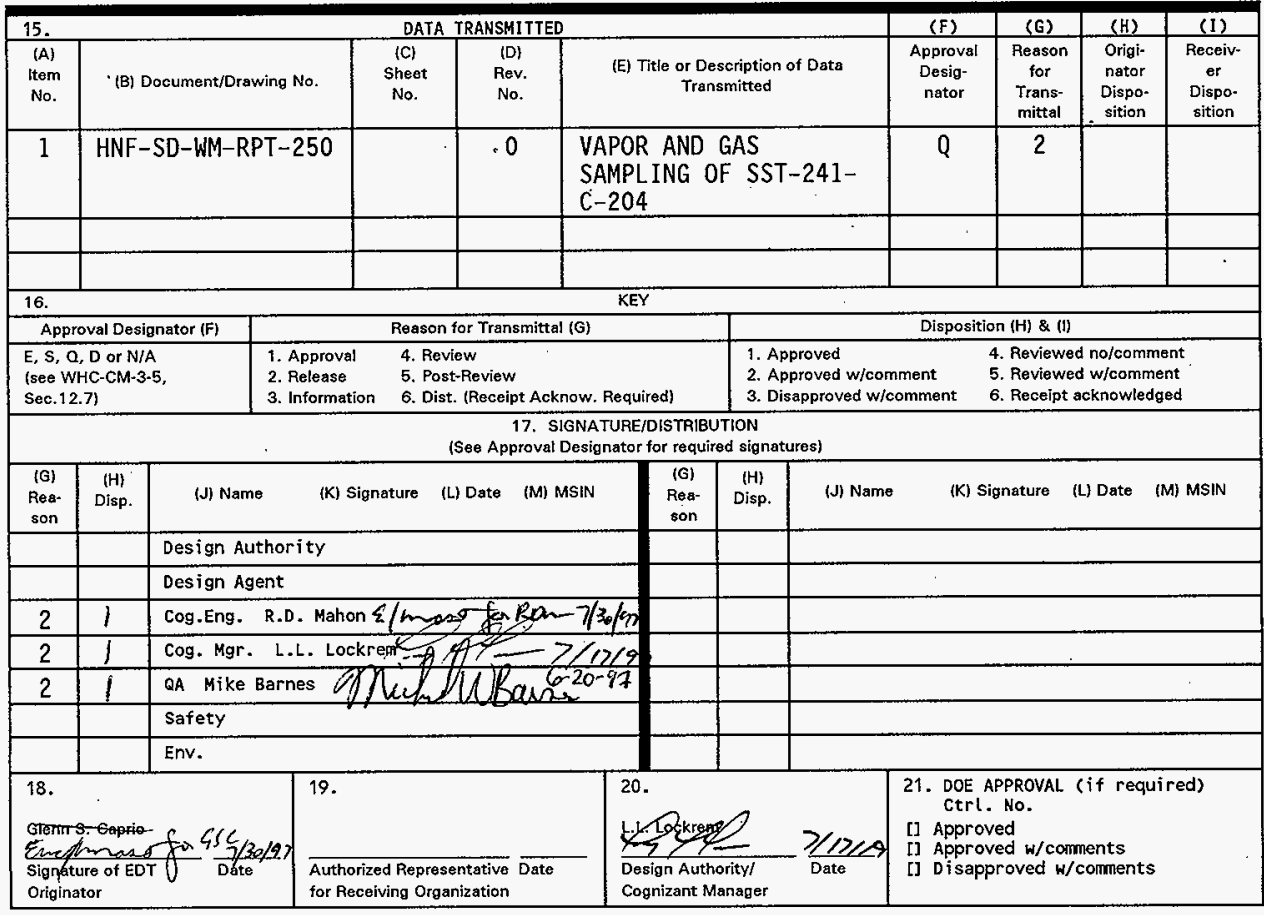




\section{VAPOR AND GAS SAMPLING OF SINGLE-SHELL TANK 241-C-204 USING the in Situ Vapor Sampling System}

\section{G.S. Caprio}

SGN Eurisys Services Company, Richland, WA 99352

U.S. Department of Energy Contract DE-AC06-96RL13200
EDT/ECN: 621269
Org Code: 8C530
UC: 2070
B\&R Code: EW3120074
Charge Code: E62000
Total Pages: 30

Key Words: 241-C-204, ISVS, SUMMA ${ }^{\mathrm{m}}$, TST, SORBENT, TANK

Abstract: THIS DOCUMENT PRESENTS SAMPLING DATA RESULTING FROM THE JULY 02, 1996 SAMPLING OF SST 24I-C-204

SUMMA is a trademark of Molectrics, Inc.

TRADEMARK DISCLAIMER. Reference herein to any specific commercial product, process, or service by trade name, trademark, manufacturer, or otherwise, does not necessarily constitute or imply its endorsement, recommendation, or favoring by the United States Government or any agency thereof or its contractors or subcontractors.

Printed in the United States of America. To obtain copies of this document, contact: Document Control Services, P.0. Box 950, Mailstop 46-08, Richland WA 99352, Phone (509) 372-2420;
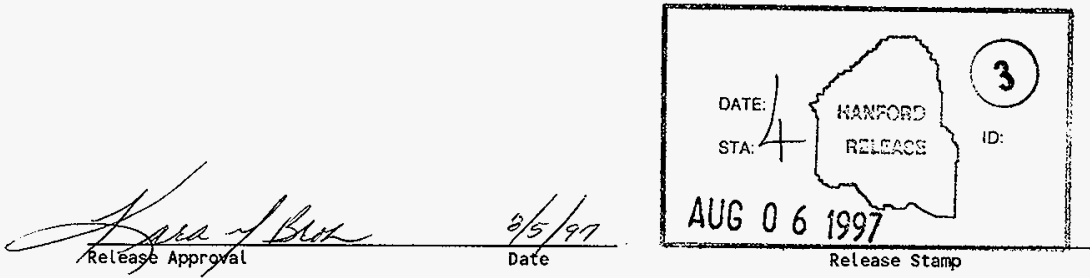
HNF - SD-WM-RPT-250, Rev. 0

\section{APPROVALS}

Document title:

Vapor and Gas Sampling of Single-Shell Tank 241-C-204 Using the In Situ vapor Sampling system

Approved by:

G. S. Caprio, Field Scientist

Date

Vapor Sampling Project

Special Analytical Studies

Approved by:

Approved by:

R. D. Mahon, Project Lead

Vapor Sampling Project

Special Analytical Studies

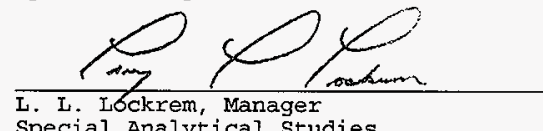

Date

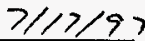




\section{CONTENTS}

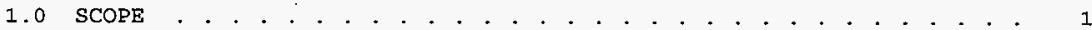

2.0 SAMPLING EQUIPMENT DESCRIPTION . . . . . . . . . . . . . . . . . . . . . 1

2.1 IN SITU VAPOR SAMPLING SYSTEM . . . . . . . . . . . . . . . . . 1

3.0 SAMPLING EVENT DESCRIPTION . . . . . . . . . . . . . . . . . . . . . 2

3.1 SPECIFICATIONS . . . . . . . . . . . . . . . . . . . . . . . . . . . 2

3.2 OPERATIONS AND SAMPLING PERSONNEL . . . . . . . . . . . . . . . . . . . . . 2

3.3 INDUSTRIAI HYGIENE FIEID RESULTS . . . . . . . . . . . . . . . . . 2

3.4 AMBIENT CONDTTIONS . . . . . . . . . . . . . . . . . . . . . . . . . . . . . . . .

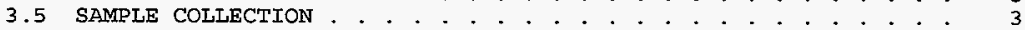

3.6 RADIATION SCREENING . . . . . . . . . . . . . . . . . . . . . . 3

4.0 SAMPIE CHAIN OF CUSTODY: RECEIPT, STORAGE, AND SHIPMENT . . . . . 4

5.0 QUAZITY ASSURANCE AND CONTROLS . . . . . . . . . . . . . . . . . . . 5

5.1 CLEANLINESS OF SYSTEM . . . . . . . . . . . . . . . . . . . . . . 5

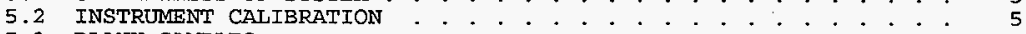

5.3 BLANK SAMPLES . . . . . . . . . . . . . . . . . . . . . . . . . . . . . . . . 6

6.0 AnOMAlies . . . . . . . . . . . . . . . . . . . . . 6

7.0 REFERENCES . . . . . . . . . . . . . . . . . . . 7

\section{APPENDICES}

SAMPLE IOG SHEETS . . . . . . . . . . . . . . . . . . . . . . . . . . . A- 1

AMBIENT CONDITIONS . . . . . . . . . . . . . . . . . . . . . . . . B-1

CHAIN-OF-CUSTODY FORMS . . . . . . . . . . . . . . . . . . . . . . . . C-1 
HNF-SD-WM-RPT-250, Rev. 0

LIST OF TABLES

1. Radionuclide Analysis Results . . . . . . . . . . . . . . . . . . . . 4

2. Calibration Data . . . . . . . . . . . . . . . . . . . 5

3. Totalizer Calibration Data . . . . . . . . . . . . . . . 6 
HNE-SD-WM-RPT-250, Rev. 0

\section{IIST OF TERMS}

CGI

$\mathrm{COC}$

DOT

GEA

ISVS

$\mathrm{NH}_{3}$

$\mathrm{H}_{2} \mathrm{O}$

OPC

OVM

PNNL

SAS

SHA

SML

SST

TCF

TOC

TST

VT

WHC

Combustible Gas Indicator Chain of Custody

U.S. Department of Transportation

Gamma Energy Analysis

In Situ Vapor Sampling system

Ammonia

Water Vapor

Offsite Property Control

Organic Vapor Meter

Pacific Northwest National Laboratory

Special Analytical Studies

Sample Head Assembly

Sampling and Mobile Laboratories

Single-Shell Tank

Tank Characterization Plan

Total Organic Carbon

Triple sorbent Trap

Vapor Team, personnel from Sampling and Mobile Laboratories and Special Analytical Studies

Westinghouse Hanford Company 
HNF-SD-WM-RPT-250，Rev . 0

This page intentionally left blank. 
HNF-SD-WM-RPT-250, Rev. 0

\author{
VAPOR AND GAS SAMPLING OF SINGLE-SHELI TANK 241-C-204 \\ USING THE IN SITU VAPOR SAMPLING SYSTEM
}

\title{
1.0 SCOPE
}

The Vapor Issue Resolution Program tasked the Vapor Team (VT) to collect representative headspace samples from Hanford site single-sheli tank (SST) 241-C-204. This document presents In Situ Vapor Sampling system (ISvS) data resulting from the July 2, 1996 sampling of SST 241-C-204. Analytical results will be presented in separate reports issued by the Pacific Northwest National Laboratory (PNNL) which supplied and analyzed the sample media.

\subsection{SAMPIING EQUIPMENT DESCRIPTION}

\subsection{IN SITU VAPOR SAMPIING SYSTEM}

The VT, consisting of Sampling and Mobile Laboratories (SMI) and Special Analytical studies (SAS) personnel, used the Isvs to collect representative samples of the air, gases, and vapors from the headspace of SST 241-C-204 on July 02, 1996. WHC-SD-WM-SDD-068 Rev. 0, System Design Description for the In Situ Vapor Sampling System (Blanchard 1996a) describes, in detail the IsvS performance, its characteristics, and its operation.

In situ sampling is a method designed to collect vapor samples of the homogeneous headspace of waste tanks. Sample media, consisting of sorbent traps and radiological filters, are lowered into the tank headspace. Tank gases are draw through the media by means of the Isvs manifold, which measure the volume of gas drawn through the system. The sample media are collected together in a sample head assembly (SHA). The SHA provides for twelve sorbent or triple sorbent trap (TST) samples (single sample each) to be sampled in sets of four, one SUMMA" sampling line, and one line for radiological filtration.

The SHA is protected from external contamination and breakage by a transparent plastic tube. The plastic tube is cut, formed, and connected to the SHA. The plastic tube also prevents any part of the SHA from accidentally falling into the tank.

A set of $1 / 4$ or $5 / 16$ inch diameter flexible tubes, approximately 50 feet long, are held together with spiral wrap to form a "tube bundle", which connects the ISVS to the SHA. The tube bundle and SHA are assembled prior to sampling and are referred to as the "sample assembly".

Sorbent traps are pencil-size stainless steel or glass tubes that contain vapor-adsorbing media. The sorbent traps may be used singly or may be prepared with several individual traps joined in series (a sorbent train). A known amount of sample vapor is passed through the tube, which traps (by adsorption) vixtualiy all the target analytes. The concentration of analytes in the vapor sampled is calculated from the quantity of analyte found in the sorbent media and the volume of vapor passed through the sorbent trap. In addition to the sorbent traps, SUMMA canisters are also used to collect samples.

SUMMA canisters are stainless steel vessels with internal surfaces that have been prepared by the SUMMA" process, which passivates active sites on the canister walls to minimize adsorption of gases and vapors. An analytical laboratory must clean and evacuate SUMMA canisters before each use. The 
HNF - SD-WM-RPT-250, Rev . O

evacuated canister is filled with sample vapor through a valve, which is then closed to seal the sample inside. SUMMA" canisters allow collection and transfer of whole-air samples from location to an analytical laboratory where the sample is analyzed. The standard capacity of each SUMMA canister is 6 liters.

The ISVS consists of five sample stations, (four for sorbent trap sampling and one for SUMMA sampling) terminating in $1 / 4$ inch outside diameter stainless steel tubing. Each sorbent sample station is independently operable at the selected flow rate, from 50 to 500 standard cubic centimeters per minute (sccm).

The system is a portable sampling system. It is designed to allow setup and preparation to be performed outside of the tank farm, with a minimum number of steps to be performed inside the farm. It operates on $110 \mathrm{~V}$ AC power. The ISVS was designed to meet the requirements of National Fire Protection Association 70 - 1993 (the National Electrical Code) for general industrial use. Before the ISVS can be used in any tank, procedures require a flammability check of the waste tank which shows that concentrations of flammable materials are well below lower flammability limits.

Tank gases passing through the ISVS will either pass through a sorbent trap and then a backup line dryer, or through the on-board activated charcoal/arierite cartridge. A check valve is installed in the system to prevent any possibility of siphoning materials into the waste tanks.

\subsection{SAMPLING EVENT DESCRIPTION}

\subsection{SPECIFICATIONS}

The Vapor Issue Resolution Program specifies sampling requirements in WHC-SD-WM-TP-335 Rev. 2A, Vapor Sampling and Analysis Plan (Buckley 1996b). The Sampling and Analysis plan also specifies the types and number of samples to be collected, flow rates, and durations. These key sampling parameters are summarized on the sample log sheets in Appendix A. In addition to the sample log sheets, checksheets for each individual sample help ensure correct sampling procedures. The VT retains these documents in the project file. The project specific number for this sampling event is $\mathrm{S6-067.}$

\subsection{OPERATIONS AND SAMPLING PERSONNEL}

Steve Carter was the Tank Farm Operations person-in-charge. The VT members included:

G. S. Caprio, Field Scientist

R. D. Mahon, Lead Scientist

C. S. Mcclellan, Sampling Technician.

The ISVS was set up at SST 241-C-204 on July 2, 1996 and was allowed to warm up for approximately 15 minutes. Sampling began at approximately 0944 on July 2,1996 , and was completed by 1141 the same day.

\subsection{INDUSTRIAI HYGIENE FIEUD RESULTS}

Prior to inserting the tube bundle into SST 241-C-204, an industrial hygiene technician field tested tank vapors. The technician purged the instrument with tank gas for 5 minutes and then field measured vapor stream contents 
HNF-SD - WM-RPT-250, Rev. 0

using a combustible gas indicator (CGI) and an organic vapor meter (OVM). The technician measured the tank vapors at the breather filter, three feet down the riser, and twenty six feet down the riser. The measurements reported at the breather filter: LEL $0 \frac{8}{8}, \mathrm{NH}_{3} 0 \mathrm{ppm}, \mathrm{O}_{2} 20.9 \%$, and TOC $0 \mathrm{ppm}$. The measurements approximately three feet down were: LEL $0 \%, \mathrm{NH}_{3} 0 \mathrm{ppm}, \mathrm{O}_{2} 20.8 \%$, and TOC $1.6 \mathrm{ppm}$. The measurements approximately twenty six feet down were: LEL $0 \%, \mathrm{NH}_{3} O \mathrm{ppm}, \mathrm{O}_{2} 21.0 \%$, and TOC $5.0 \mathrm{ppm}$.

\subsection{AMBIENT CONDITIONS}

The weather the day of the sampling event, July 2, 1996, was sunny and clear with a slight breeze from the northwest. Graphs of ambient temperatures and pressures taken at the Hanford Meteorological Station, which is about 6 miles north west of C-Farm, are provided in Appendix B.

\subsection{SAMPLE COLLECTION}

One analytical laboratory provided sample media. PNNL provided SUMMA" canisters, sorbent traps for organic vapors, ammonia $\left(\mathrm{NH}_{3}\right)$, $\mathrm{NO} \mathrm{x}_{\mathrm{x}}$, and water vapor $\left(\mathrm{H}_{2} \mathrm{O}\right)$.

The VT began inserting the sample media into the SHA at 1215 on July 1, 1996, and finished at approximately 1400 . The SHA was connected to tube bundle 14D. The top collar as described in $\mathrm{ECN} \# 632433$ was used for this sampling event. The sample assembly was transported to $241-\mathrm{C}-204$ on July 2, 1996, and connected to ISVS \#1 for the sampling event.

Prior to sample collection, a leak check of the ISVS sampling manifold and transfer tubing was performed. Pressure gauge readings were recorded at the beginning of the leak check. The gauge readings were used for the leak check calculations but for report purposes will be converted to absolute pressure. The system was evacuated to approximately $135.46 \mathrm{mbar}$ (4 inHg) and leakage of ambient air into the system was observed by monitoring system pressure for 5 minutes. Leakage resulted in an increase of 0 mbar (0 inHg) in system pressure during the 5 minute test.

The tank flange was opened and the tube bundle was lowered 7.925 meters (26 feet). Tank vapor was drawn through each TST, sorbent, and SUMMA" line for a specified period of time. Appendix A indicates the exact times and volumes of tank gas that was drawn through each sample.

After the final sample was collected the sample assembly was removed from the tank. Following the HPT survey the SHA was packaged as radiation material and transported back to a custody secure RMA at WSCF where it was disassembled the following day. Plugs were placed in the c-flex inlets and c-flex clamps on the 1/4 inch Tygon tubing coming out of the Top Collar to isolate the samples from ambient conditions. Following the HPT survey the SHA was packaged as radiation material and transported back to a custody secure RMA at WSCF where it was disassembled the following day. The in-line filters were transported to $222-\mathrm{s}$ for analysis.

\subsection{RADIATION SCREENING}

Radiological screening results are used to determine (1) if the samples must be shipped as radioactive or nonradioactive in accordance with U.S. Department of Transportation (DOT) regulations and (2) if the samples meet the laboratory acceptance criteria.

The DOT limits for shipping a nonradioactive sample are 2000 combined pCi/g of beta-gamma activity and alpha activity. Samples exceeding these DOT'limits 
may be shipped as radioactive material if the samples do not exceed the following laboratory acceptance criteria:

PNNL: Beta-gamma activity $<15 \mathrm{pCi} / \mathrm{g}$ of sample media. Alpha activity $<5 \mathrm{pCi} / \mathrm{g}$ of sample media.

The sample media was not filtered for radiological particulates. The idea of unfiltered samples was to provide better analytical data for the laboratories. The samples were released for shipment based on a the analytical results of the series of two filters and tritium trap collected through one of the $1 / 4$ inch flexible lines. Based on the radiological results for the filters and tritium trap it is believed that the same concentration of radiological contaminates passed through the other 13 lines. The filters were analyzed by 222 -S Laboratory. Based on the analytical results provided in Table I the samples were shipped to PNNL and delivered to J. A. Edwards. The VT scientists use the activity results in Table 1 to calculate $\mathrm{pCi} / \mathrm{g}$ of sample media. The VT maintains this information in the project-specific file.

Table 1. Radionuclide Analysis Results.

\begin{tabular}{|l|c|c|c|}
\hline \multicolumn{1}{|c|}{ Filter } & $\begin{array}{c}\text { Sample } \\
\text { Identifier }\end{array}$ & $\begin{array}{c}\text { Activity Results } \\
\text { (pCi/sample) }\end{array}$ & $\begin{array}{c}\text { Activity } \\
\text { (pCi/L of tank gas) }\end{array}$ \\
\hline Upstream filter & S6067-A21.0U1 & $\begin{array}{c}\text { Total Alpha =<4.58 } \\
\text { Total Beta }=22.10 \\
\text { GEA = <detectable }\end{array}$ & $\begin{array}{c}=<\text { detectable } \\
=22.10 \\
=<\text { detectable }\end{array}$ \\
\hline Downstream filter & S6067-A22.OD1 & $\begin{array}{l}\text { Total Alpha = I.50 } \\
\text { Total Beta = <1.35 } \\
\text { GEA = <detectable }\end{array}$ & $\begin{array}{c}=1.50 \\
=<\text { detectable } \\
=<\text { detectable }\end{array}$ \\
\hline Tritium Trap & S6067-A03.OT1 & Total Activity=<2.9 & $=<$ detectable \\
\hline
\end{tabular}

NOTES:

The samples are nonradioactive. These results were evaluated against laboratory acceptance criteria and DOT limits.

aAll less than (<) values represent the minimum detection limits at Laboratory $222-\mathrm{S}$. filters.

Numbers based on 1 liter for the total volume of tank vapor through the

\subsection{SAMPLE CHAIN OF CUSTODY: RECEIPT, STORAGE, AND SHIPMENT}

All sorbent trains, TSTs, and SUMMA" canisters received from PNNL are kept in a custody locked storage area maintained by SMU. Sorbent trains and TSTs were maintained at $4 \pm 2{ }^{\circ} \mathrm{C}$ in a refxigeration unit. SUMMA ${ }^{m}$ canisters were stored in the same locked storage area, but were not refrigerated. The sample media was picked up from PNNL by SAS and transported in a government vehicle to a custody locked storage area. Appendix C lists the sample identifiers, sample types, and COC form numbers for the sampling event.

From the time that samples are received by SAS until they are shipped back to the analytical laboratory, all COCs are maintained by SAS in accordance with WHC-IP-1127-1.3, Chain-of-Custody/Special Analysis Request for RCRA and CERCLA Protocol Samples (WHC 1995a). 


\subsection{QUALITY ASSURANCE AND CONTROLS}

\subsection{CLEANLINESS OF SYSTEM}

Immediately prior to sampling of SST 241-C-204, the ISVS manifold was purged with ambient air for 5 minutes at $1 \mathrm{~L} / \mathrm{min}$. After this purge an ambient air SUMMA" sample was drawn through the ISvS manifold and the $1 / 4$ inch SUMMA sampling line. A second ambient air SUMMA" sample was collected 10 meters upwind from the tank breather filter. The ambient aix samples were then collected to confirm by laboratory analysis that the ISVS sampling manifold was free of trace organic contaminants (or to determine which contaminants were present and at what concentration). For further details, refer to WHC-IP-1127-4.8 (WHC 1995b) and the project-specific file located with the VT.

\subsection{INSTRUMENT CALIBRATION}

The ISVS uses mass flow meters to measure the flow rate and totalizers to measure the total volume of sample vapor drawn through the sample media. Errors associated with the mass flow meters and totalizers were determined by the Westinghouse Hanford Company (WHC) Standards Laboratory before the SST 241-C-204 sampling event. Duration of flow are specified by the analytical laboratories that supply and analyze the sorbent traps.

"Due to calibiation discrepancies, the mass flow measurements for this sampling event may have an error of $6 \%$ to $14 \%$. A detailed description of this discrepancy can be found in internal memo 75820-96-028".

Table 2. Calibration Data.

\begin{tabular}{|c|c|c|c|}
\hline Element & Calibration Date & Expiration Date & $\begin{array}{l}\text { WHC Standards } \\
\text { Laboratory Code }\end{array}$ \\
\hline $\begin{array}{c}\text { Rotameter AALBORG } \\
102-05\end{array}$ & $8 / 8 / 95$ & $8 / 8 / 96$ & $518-28-13-001$ \\
\hline $\begin{array}{c}\text { Digital } \\
\text { Thermometer HH22 }\end{array}$ & $1 / 11 / 96$ & $1 / 11 / 97$ & $518-79-06-003$ \\
\hline $\begin{array}{l}\text { Vacuum Gauge } \\
\text { ASHCROFT }\end{array}$ & $8 / 7 / 95$ & $8 / 7 / 96$ & $518-31-05-003$ \\
\hline $\begin{array}{l}\text { Headspace } \\
\text { Thermocouple }\end{array}$ & $5 / 31 / 96$ & $5 / 31 / 97$ & $518-78-02-010$ \\
\hline $\begin{array}{c}\text { Mass Flowmeters } \\
\text { Sierra } 822-13-\text { OV1 } \\
\text { FM-1/FT-1 }\end{array}$ & $8 / 8 / 95$ & $8 / 8 / 96$ & $518-28-03-015$ \\
\hline $\begin{array}{c}\text { Mass Flowmeters } \\
\text { Sierra } 822-13-\text { OV1 } \\
\text { FM-2/FT- } 2\end{array}$ & $8 / 8 / 95$ & $8 / 8 / 96$ & $518-28-03-016$ \\
\hline $\begin{array}{c}\text { Mass Flowmeters } \\
\text { Sierra } 822-13-\text { OV1 } \\
\text { FM-3/FT-3 }\end{array}$ & $8 / 8 / 95$ & $8 / 8 / 96$ & $518-28-03-017$ \\
\hline $\begin{array}{c}\text { Mass Flowmeters } \\
\text { Sierra } 822-13-\text { OV1 } \\
\text { FM- } 4 / \text { FT - } 4\end{array}$ & $8 / 8 / 95$ & $8 / 8 / 96$ & $518-28-03-018$ \\
\hline
\end{tabular}

Instruments located in the ISVS are calibrated on an annual basis at the WHC Standards Laboratory. ISVS instrumentation calibration data, maintained in 
HNF-SD-WM-RPT-250, Rev. 0

files by the VT, are summarized in Table 2. According to the calibration schedule shown in Table 2 , all instrumentation was within its calibration period during the SST 241-C-204 sampling event.

The totalizers were calibrated in conjunction with the mass flow meters and the calibration data is summarized in Table 3 .

Table 3. Totalizer Calibration Data.

\begin{tabular}{|c|c|c|c|c|c|c|c|}
\hline Number & $\begin{array}{c}\text { Calibration } \\
\text { Date }\end{array}$ & $\begin{array}{c}\text { Expiration } \\
\text { Date }\end{array}$ & $\begin{array}{l}\text { Flow Rate } \\
\left.\text { (stdcm }{ }^{3} / \mathrm{min}\right)\end{array}$ & $\begin{array}{l}\text { Time } \\
\text { (min) }\end{array}$ & $\begin{array}{l}\text { Calc. } \\
\text { Total }\end{array}$ & UUT & Deviation \\
\hline $\begin{array}{c}3494-1 \\
F T-1\end{array}$ & $8 / 8 / 95$ & $8 / 8 / 96$ & 247.1 & 5.833 & 1441.2 & 1500 & $3.9 \%$ \\
\hline $\begin{array}{c}3494-2 \\
\text { FT-2 }\end{array}$ & $8 / 8 / 95$ & $8 / 8 / 96$ & 253.8 & 7.065 & 1793.1 & 1800 & $0.4 \%$ \\
\hline $\begin{array}{c}3494-3 \\
\mathrm{FT}-3\end{array}$ & $8 / 8 / 95$ & $8 / 8 / 96$ & 262.7 & 5.081 & 1334.7 & 1300 & $2.6 \%$ \\
\hline $\begin{array}{c}3494-4 \\
\text { FT }-4\end{array}$ & $8 / 8 / 95$ & $8 / 8 / 96$ & 25.2 & 5.186 & 1302.8 & 1300 & $0.2 \%$ \\
\hline
\end{tabular}

\subsection{BLANK SAMPLES}

Trip blanks are samples that accompany the sample media from the point of generation through sample analysis. They are transported to the field with the sample collection media but remain unopened during the sampling event. Analysis of trip blanks is used to assess cross-contamination of sample media during field transport and storage.

Field blanks are sampling devices similar to trip blanks. They are prepared and handled in the same manner as the sampling media, but no tank vapors are drawn through them.

Spiked blanks are prepared as regular sampling media but also contain a known amount of special analyte. Tank vapors are drawn through these blanks and they are handled and analyzed just like any other sample. Analysis of the spiked blanks is used to evaluate potential sample loss during shipment or storage.

Ambient blanks are samples of ambient air collected at the sampling location. Analysis of ambient blanks is used to assess contamination that may be present in the atmosphere or in the transfer tubing or sampling manifold of the Isvs immediately prior to sampling operations.

\subsection{ANOMALIES}

The VT used the Sampling and Analysis Plan and WHC-IP-1127-4.8, Vapor Sampling of Waste Tanks Using In Situ Vapor Sampling System (ISVS), (1995b) to guide the sample collection. Anomalies noted during the sample collection are briefly described below.

Moisture drops appeared on the SUMMA" cannister fitting of SUMMA" \#184 but were not visible in the sample line. 
HNF - SD - WM-RPT-250, Rev. 0

\subsection{REFERENCES}

49 CFR 100-177, 1992, "Transportation," Code of Federal Regulations, as amended.

Blanchard, R. J., 1996a, System Design-Description for the In Situ vapor Sampling System, WHC-SD-WM-SDD-068 Rev. 0, Westinghouse Hanford Company, Richland, Washington.

Washington.

Buckley, I. I., 1996b, Vapor Sampling and Analysis Plan, WHC-SD-WM-TP-335 Rev. 2A, Westinghouse Hanford Company, Richland, Washington.

Trible, T. C., Viswanath, R. S., 1996c, Recommendation concerning the ISVS/VSS comparison study data with respect to calibration errors in Mass flow monitors and controllers, (internal memo 75820-96-028 to L.D. Pennington, August 28), Westinghouse Hanford Company, Richland, Washington.

WHC, 1995a, Chain-of-Custody/Special Analysis Request for RCRA and CERCLA Protocol Samples, Procedure WHC-IP-1127-1.3, Rev. I, Westinghouse Hanford Company, Richland, Washington.

WHC, 1995b, Vapor Sampling of Waste Tanks Using In Situ Vapor Sampling System (ISVS), Procedure WHC-IP-1127-4.8, Westinghouse Hanford Company,

Richland, washington. 
HNF - SD - WM-RPT- 250, Rev. O

This page intentionally left blank. 
HNF - SD-WM-RPT-250，Rev. 0

APPENDIX A

SAMPLE LOG SHEETS

A-1 
HNF-SD-WM-RPT-250， Rev . 0

This page intentionally left blank. 
ISvS Sampling of C-204

Set up ISVS (Secton 8.1)

Ensure particulate filters are installed

LEAK CHECK(APPENDIX I) Leak Rate:

Tank Temperature

Ambient Temp.

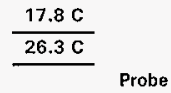

WHC Sample ID

PNNL Sample

Sample ID Line Port

Date: $7 / 2 / 96$

ISVS Personnel: Glenn Caprio, Rick Mahon, Chuck McClellan

Trailer Personnel: None

0 inch $\mathrm{Hg}$ in $5 \mathrm{~min}$

\section{Trailer Personnel. None}

\begin{tabular}{lccccccc} 
Fesired & Desired & Desired & Actual & Actual & Actual & Actual & Actual \\
Flow & Duration & Total & Flow & Start & End & Total & Total \\
Rate & (min.) & Flow & Rate & Time & Time & Time & Flow \\
Sccm & & scc & Sccm & & & (min.) & Scc \\
1000 & 5 & 5000 & 1000 & 0946 & 0951 & 5 \\
\hline & 1 & & & 0948 & 0949 & 1 \\
\hline
\end{tabular}

\begin{tabular}{|c|c|c|c|c|c|c|c|c|c|}
\hline S6067 A01. 126 & 126 & NA & NA & Upwind SUMMA & $\# 1$ & 1 & 0948 & 0949 & 1 \\
\hline 56067 A02. 166 & 166 & $s$ & SUMMA & Bundle Ambient & $\# 2$ & 1 & 0951 & 0951 & 1 \\
\hline
\end{tabular}

. ... Uncap and insert sample bundle into tank

1017

1141

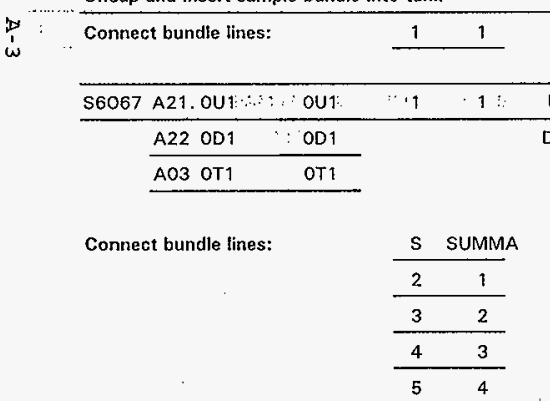

\begin{tabular}{|c|c|c|c|c|c|c|c|c|c|c|c|c|}
\hline \multicolumn{2}{|c|}{ Purge Suma line / $w$ tank } & $\mathrm{s}$ & SUMMA & SUMMA purge & 1000 & 5 & 5000 & 1000 & 1033 & 1038 & 5 & 5000 \\
\hline 56067 A04. 136 & 136 & $s$ & SUMMA & Summa $\# 3$ & & 1 & & & 1038 & 1039 & 1 & 6000 \\
\hline 56067 A05. 153 & 153 & $s$ & SUMMA & Summa $\# 4$ & & 1 & & & 1046 & 1047 & 1 & 6000 \\
\hline
\end{tabular}


ISVS Sampling of C-204

\begin{tabular}{|c|c|c|c|c|c|c|c|c|c|c|c|c|}
\hline WHC Sample 1D & $\begin{array}{c}\text { PNNL } \\
\text { Sample ID }\end{array}$ & $\begin{array}{c}\text { Probe } \\
\text { Sample } \\
\text { Line }\end{array}$ & $\begin{array}{l}\text { Cart } \\
\text { Port }\end{array}$ & Description & $\begin{array}{c}\text { Desired } \\
\text { Flow } \\
\text { Rate } \\
\text { sccM }\end{array}$ & $\begin{array}{c}\text { Desired } \\
\text { Duration } \\
\text { (min.) }\end{array}$ & $\begin{array}{l}\text { Desired } \\
\text { Total } \\
\text { Flow } \\
\text { scc }\end{array}$ & $\begin{array}{l}\text { Actual } \\
\text { Flow } \\
\text { Rate } \\
\text { sccm }\end{array}$ & $\begin{array}{l}\text { Actual } \\
\text { Start } \\
\text { Time }\end{array}$ & $\begin{array}{l}\text { Actual } \\
\text { End } \\
\text { Time }\end{array}$ & $\begin{array}{l}\text { Actual } \\
\text { Total } \\
\text { Time } \\
\text { (min.) }\end{array}$ & $\begin{array}{c}\text { Actual } \\
\text { Total } \\
\text { Flow } \\
\text { scc }\end{array}$ \\
\hline S6067 A06. 184 & 184 & $s$ & SUMMA & Summa \#5 & & 1 & & & 1052 & 1053 & 1 & 6000 \\
\hline S6067 A07. $22 R$ & 228 & 2 & 1 & $\mathrm{NH} / \mathrm{NO} / \mathrm{H} 2 \mathrm{O}$ & 200 & 10 & 2000 & 215 & 1101 & NA & NA & 2002 \\
\hline S6067 A08. 23A & $23 R$ & 3 & 2 & $\mathrm{NH} 3 / \mathrm{NO} / \mathrm{H} 2 \mathrm{O}$ & 200 & 10 & 2000 & 208 & $1101: 30$ & NA & $\therefore$ NA & 1998 \\
\hline S6067 A09. $24 \mathrm{R}$ & $24 \mathrm{R}$ & 4 & 3 & $\mathrm{NH} 3 / \mathrm{NO} / \mathrm{H} 2 \mathrm{O}$ & 200 & 10 & 2000 & 210 & 1102 & NA & NA & 2000 \\
\hline S6067 A10. $25 R$ & $25 R$ & 5 & 4 & $\mathrm{NH} 3 / \mathrm{NO} / \mathrm{H} 2 \mathrm{O}$ & 200 & 10 & 2000 & 205 & $1102: 30$ & NA & NA & 1999 \\
\hline
\end{tabular}

Connect bundle lines:

\begin{tabular}{cc}
6 & 1 \\
\hline 7 & 2 \\
\hline 8 & 3 \\
\hline 9 & 4 \\
\hline
\end{tabular}

W

(2)
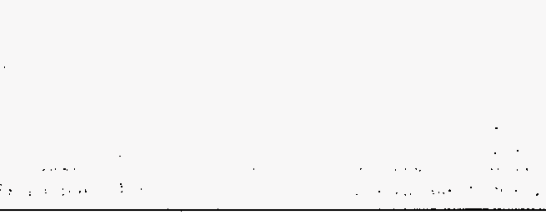

$1130 \quad 1141$


ISVS Sampling of C-204

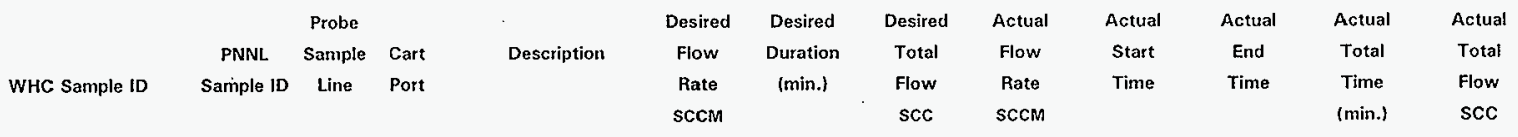

Remove filters from cart manifold ports $1,2,3,4$, and SUMMA to release cart. 


\begin{tabular}{|c|c|c|c|}
\hline 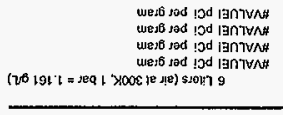 & 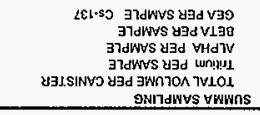 & & \\
\hline 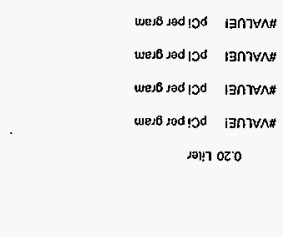 & 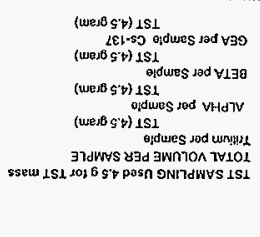 & 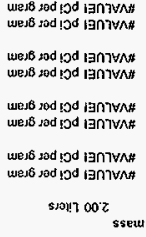 & 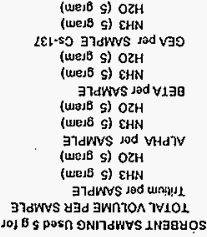 \\
\hline
\end{tabular}

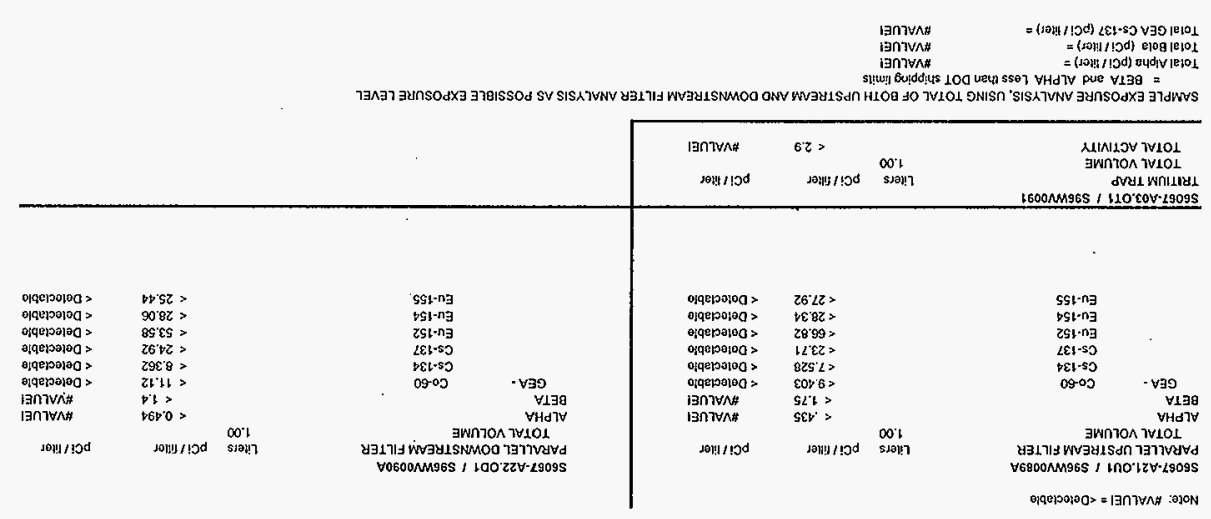


HNE - SD-WM-RPT-250，Rev. 0

APPENDIX B

AMIEIENT CONDITIONS

B - 1 
HNF - SD - WM-RPT-250，Rev, 0

This page intentionally left blank. 
WEATHER DURING ISVS SAMPLING OF 241-C-204

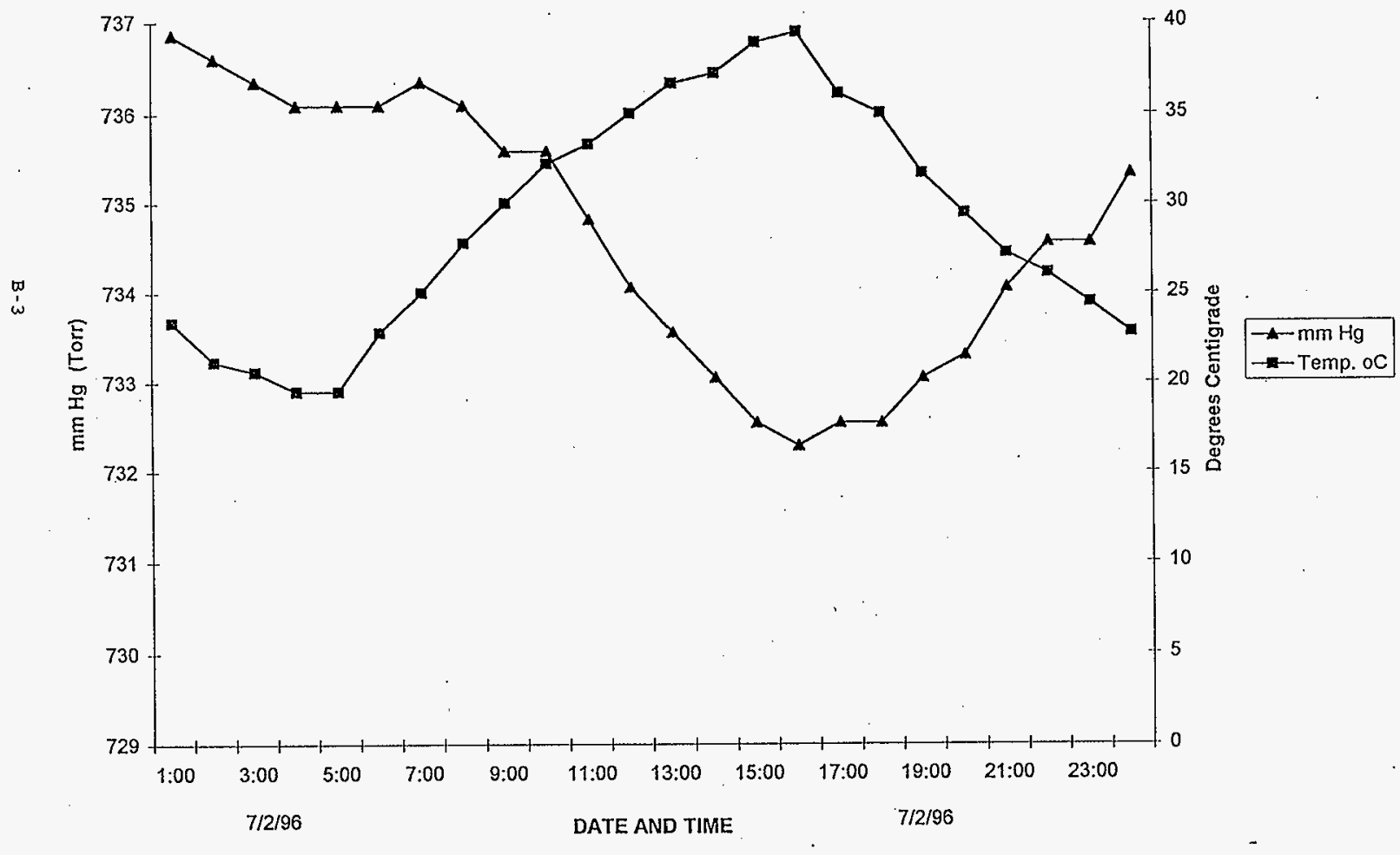


HNF - SD -WM-RPT-250， Rev . 0

This page intentionally left blank.

B - 4 
HNF - SD-WM-RPT-250, Rev. 0

APPENDIX C

CHAIN-OF - CUSTODY FORMS

C-1 
HNF - SD -WM-RPT-250， Rev. 0

This page intentionally left blank. 
HNE -SD-WM-RPT-250, Rev. 0

\begin{tabular}{l|lll}
\hline $\begin{array}{l}\text { Battelle Pacific } \\
\text { National Northwest Lab }\end{array}$ & CHAIN OF CUSTODY & WHC & 100247 \\
\hline
\end{tabular}

Custody Form Initiator

J. A. Edwards - PNNL

Telephone

(509) 373.0141

Page $85-3009$ / FAX 376-2329

Company Contact

R. D. Mahon - WHC

Telephone

(509) 373-2891

Page 85-3656 / FAX 373-3793

Project Designation/S ampling Locations 200 West Tank Farm

241-C-204 Tank Vapor Sample SAF $\$ 6067$

Collection date $07 \cdot \underline{2} \cdot 96$

Preparation date $06 \cdot \overline{26} \cdot 96$

Ice Ches: No.

(ISVS Cart)

Field Logbook No. WHC-N 697.8

Bill of Lading/Airbill No.

N/A

Offsite Property No. N/A

Method of Shipment

Government Truck

Shipped to

PNNL

Possible Sample Hazards/Remarks Unkrown at time of sampling

S6067 - A01 . 126 .

$S 6067-\mathrm{A02} .166$.

$\mathrm{S} 6067$ - A04 . 136

$\mathrm{S} 6067$ - A.05 . 153

S6067 - A06. 184
Collect Ambient Air Sample SUMMA \#1

Collect Ambient Air Sample SUMMA \#2 (through tube bundle)

Collect SUMMMA \#3

Collect SUMMA \#4

Collect SUMMA $\$ 5$

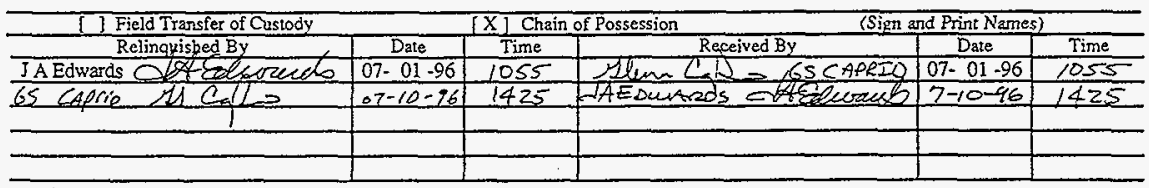

Comments:

Final Sample Disposition

PNNL (onlv) Checklist

Media labeled and checked?

Letter of instruction?

Media in good condition?

COC info/signanires complete?

Rad release stickers on samples?

Activity report from $222 S$ ?

RSR/release? (a $\leq 100 / \mathrm{B} \leq 400 \mathrm{pCi} / \mathrm{g}$ )

COC copy for LRB, RIDS filed?

(WHC-SD-WM-TP-335, REV.2, Table 2b)

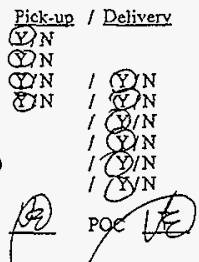

Comments:

(Revised 05/30/96 PNNL) 
HNF - SD-WM-RPT-250，Rev. 0

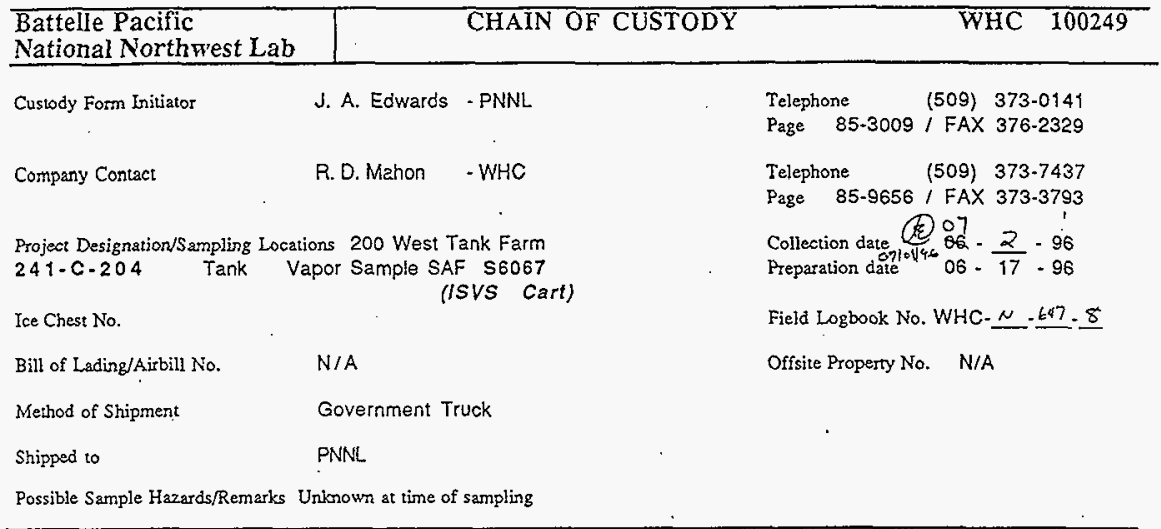

Sample Identification

$\begin{array}{ll}\text { S6067 - A07.22R. } & \text { Collect } \mathrm{NH}_{3} / \mathrm{NO}_{\mathrm{X}} / \mathrm{H}_{2} \mathrm{O} \text { Sorbent Trap } \\ \text { S6066 - A08.23R. } & \text { Collect } \mathrm{NH}_{3} / \mathrm{NO}_{\mathrm{X}} / \mathrm{H}_{2} \mathrm{O} \text { Sorbent Trap } \\ \text { S6067 - A09.24R. } & \text { Collect } \mathrm{NH} 3 / \mathrm{NO}_{\mathrm{X}} / \mathrm{H}_{2} \mathrm{O} \text { Sorbent Trap } \\ \text { S6067 - A10.25R. } & \text { Collect } \mathrm{NH} 3 / \mathrm{NO}_{\mathrm{X}} / \mathrm{H}_{2} \mathrm{O} \text { Sorbent Trap }\end{array}$

S6067- A15. 26R、 Open, close and store $\mathrm{NH}_{3} / \mathrm{NO}_{\mathrm{X}} / \mathrm{H}_{2} \mathrm{O}$ field blank $\# 1$

S6067 - A16.27R. Open, close and store $\mathrm{NH}_{3} / \mathrm{NO}_{\mathrm{X}} / \mathrm{H}_{2} \mathrm{O}$ field blank ${ }_{2} 2$

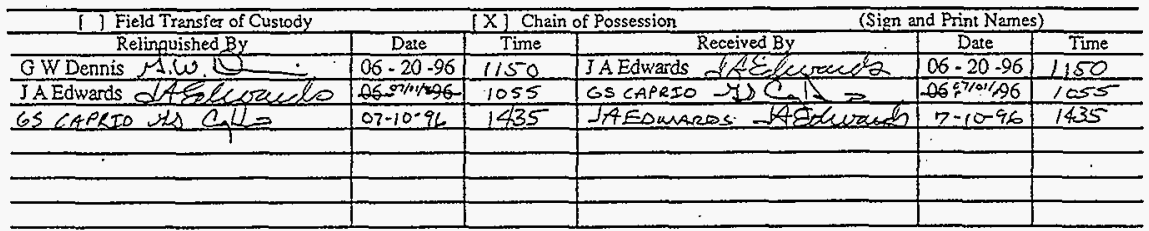

Comments:

Final Sample Disposition

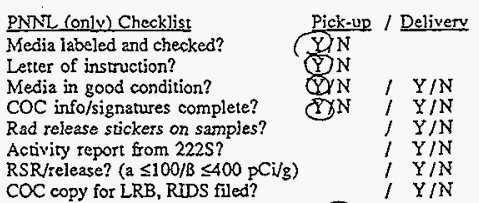

(WHC-SD.WM-TP-335.REY. 2, Tab]e 2b) A-6000-407 (12/92) WEF061

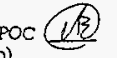

$\mathrm{POC}$
(Revised 05/30/96 PNNL) 


\begin{tabular}{|c|c|c|}
\hline $\begin{array}{l}\text { Battelle Pacific } \\
\text { Northwest Laboratory }\end{array}$ & CHAIN OF CUSTODY & WHC 100248 \\
\hline
\end{tabular}

Custody Form Initiator

J. A. Edwards - PNL

Company Contac

R. D. Mahon - WHC

Project Designation/Sampling Losacions 200 West Tank Farm 241-C-204 Tank

Vapor Sample SAF S6057

(ISVS Cart)

Ice Chest No.

Enco Hi/Lo thermometer No.

Bill of Lading/Airbill No.

Method of Shipment

Shipped to

PNL-T.003 3

N/A

Government Truck

WHC.
Telephone (509) 373-0141

Page $\quad 85-3009 /$ P8.08/FAX 376-0418

Telephone (509) 373.7437

Page 85-9656/ $\$ 3.27 /$ FAX 373.7076

Collection date

$07-2 \geq \cdot 96$

Preparation date

$06 \cdot 22-96$

Field Logbook Na WHC-N 647.8

Offsite Properiy No. N/A

Possible Sample Hazards/Remarks Cinbnown at time of samplins

Sample Identification

S6067 - A11 . 1077 :

\$6067 - AI2, 1078 .

$\$ 6067$ - A13 . 1079 .

$\$ 6067$ - A14 . 1080 .

S6067 - A17 - 1081:

$\$ 6067$ - A18 . 1082 .

56067 - A19 . 1083.

$\$ 6067$ - A20. 1084 .
PNL Triple Sorbent Trap (TST) Sample \# 1

PNL TST Sample \# 2

PNL TST Sample \# 3

PNL TST Sample $\stackrel{\#}{\pi} 4$

Open, close \& store TST Field Blank \# 1

Open, ciose \& store TST Field Blank

Store TST Trip Blank

Store TST Trip Blank $\# 2$

\begin{tabular}{|c|c|c|c|c|c|}
\hline \multicolumn{2}{|l|}{ [ ] Field Transfer of Custody } & \multicolumn{4}{|c|}{ [X] Chain of Possession } \\
\hline Relinquished By & Date & Time & Received By & Date & Time \\
\hline Clontallues & $07-01.96$ & 0945 & JA Edwards $\alpha \frac{A}{t}$ salcesaceto & $07.01-96$ & 0945 \\
\hline JA Edwards $648<1<10<0$ & $07-01.96$ & 1055 & Is caprio $=2 \mathrm{C} / \alpha$ & $07-01-96$ & 1055 \\
\hline $\cos$ CAPRIR os $<s$, & $0>-10-46$ & 1430 & IA Eowares difelusuds & $7-10-96$ & 1480 \\
\hline - & & & & & \\
\hline & & & & & \\
\hline & & & & & \\
\hline & & & & & \\
\hline
\end{tabular}

\section{Comments:}

PNI (onjv) Checklist

Media labeled and checkeơ?

Letter of instruction?

Media in good condition?

COC infolsignatures compiete?

Sorbents shipped on ice? $\left(\sigma^{\circ} \mathrm{C}\right)$

Hilo thermometer - Keep upright!

$\mathrm{Hi} / \mathrm{L} \mathrm{O}$ thermometer

Rad release stickers on samples?

Activity report from 222S?

COC copy for LRB, RIDS filed?

Final Sampie Disposition

Dick-ug / Deliverv

Y YN

YN

YIN I Y/N

QIN I YIN

ชิN, Y Y IN

(Y) N

$1 \mathrm{Y} / \mathrm{N}$

, $\mathrm{Y} / \mathrm{N}$

$1 \mathrm{Y} / \mathrm{N}$

, $\mathrm{Y} / \mathrm{N}$

POC comments:

1. Cooler Temperature Stanus $\mathrm{Hii}-15^{\circ} \mathrm{C} / \mathrm{LO}-15^{\circ} \mathrm{C}$ (pick up at PNL to $\mathrm{WHC}$ )

$1 \mathrm{Hi} \_{ }^{\circ} \mathrm{C} / \mathrm{LO} \ldots{ }^{\circ} \mathrm{C}$ (delivery at WHC from PNL)

$\mathrm{Hi}-{ }^{\circ} \mathrm{C} / \mathrm{LO}^{\circ} \mathrm{C}$ (at return to PNL from WHC)

Hi $+22^{\circ} \mathrm{C} / \mathrm{LO}=8^{\circ} \mathrm{C}$ (at deliverv from WHC to PNLL

(Revised 05/21/95 PNL) 


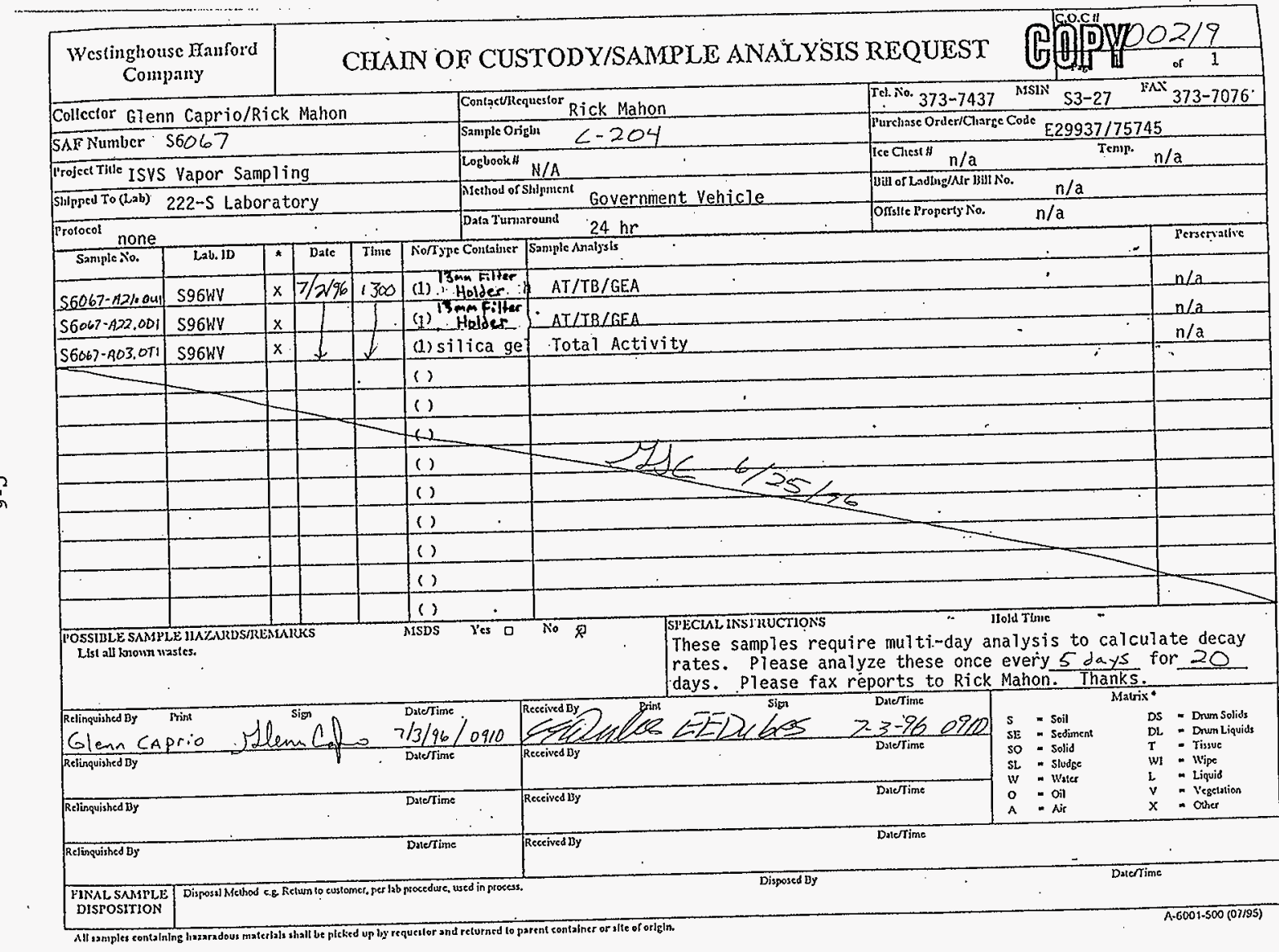




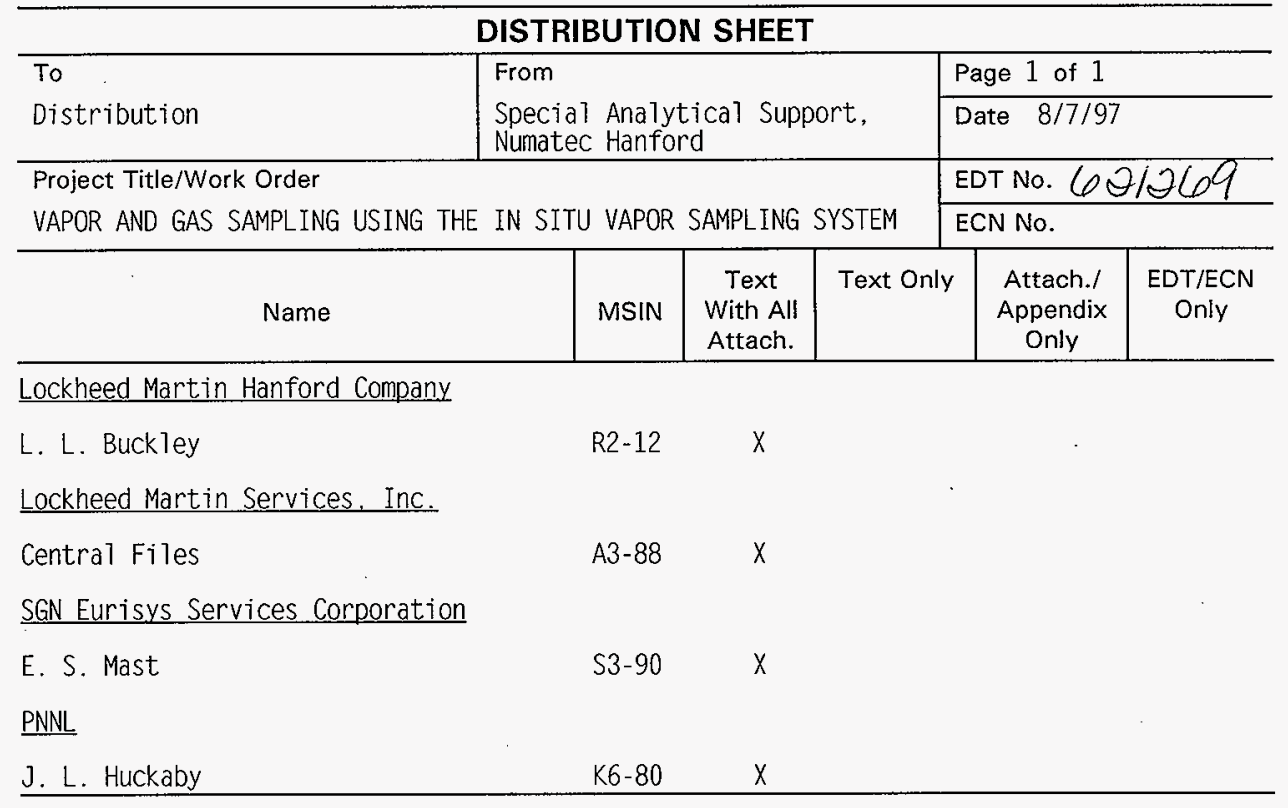

